\title{
A MAGYAR ÁLLAMTÉR VÁLTOZÁSAINAK TÖRTÉNETI ÉS POLITIKAI FÖLDRAJZI SZEMLÉLETE A MAGYAR FÖLDRAJZTUDOMÁNYBAN 1948-IG
}

\author{
(Historical and Political geographical views of the transitions of the \\ territory of the Hungarian state until 1948)
}

\section{HAJDÚ ZOLTÁN}

\section{Bevezetés}

Magyarország térfogalma és a mindenkori magyar állam által uralt államterület történetileg alakult, a változás és a stabilitás korszakonként sajátos módon jelent meg. Történetileg korán kialakult a térrel, az új szállásterülettel való azonosulás azon tudata, hogy a honfoglalás időszakában megszerzett terület az „eredeti”, majd ehhez később a „hóditás jogán” újabb területek társultak.

Létrejöttétől 1526-ig a magyar királyság környezetének egyenrangú hatalma (ezt a kor szokásai szerint ki is fejezte, a kettős kereszt beiktatása a jelvényekbe a Bizánccal való egyenjogúságot hivatott szimbolizálni a 12. század végétöl), a belsö folyamatoktól, trónviszályoktól, felkelésektöl függően esetenként gyengébb, hosszabb távon azonban a legtöbb stratégiai irányban erősebb, közép-, ső́t nagyhatalmi ambíciókkal rendelkezỏ állama, mely képes volt meghatározott érdekeit érvényesíteni.

A magyar állam történetének egyik tragédiája, hogy a délkeleti irányból jelentkező hosszú távú világhatalmi kihívásnak, a török hódításnak nem tudott ellenállni. Nemcsak vereséget szenvedett, $s$ korábbi hatalmi alapállása megszünt, hanem területe is felosztottá, vallási, kulturális, politikai világhatalmi uttközózónává alakult.

A tơrök elleni felszabadító háborúk után - a magyar nemesség által alkotmányosan legitimált módon - az ország beilleszkedett a Habsburg-ház európai hatalmi terébe, de ez a beilleszkedés nem mindenki számára vált elfogadottá és elfogadhatóvá. A közjogi vitákon túl ezt jelezték a nemzeti-függetlenségi felkelések, s köztük kitüntetetten a Rákóczi- és az 1849-es szabadságharc.

A dualizmus a közjogi és alkotmányos viták, valamint a történeti hivatástudat sajátos újratermelésének idöszaka, hiszen a szélesebb társadalmi közvéleményben, valamint 
több tudományban, köztük a földrajztudományban is, megfogalmazódott az új nagyhatalmiság eszménye.

Az I. világháborús vereség után történeti területének maradványain függetlenné váló Magyarország nem tudott igazán örülni a teljes szuverenitás kivívásának, hiszen az együttjárt korábbi, részben valós, részben pedig vélelmezett hatalmi állásának eltủnésével.

A II. vilảgháborủ előtti, alatti és az 1947-es országhatár változások azt mutatták, hogy az ország helyzete elsődlegesen a világpolitika és szomszédsági kölnyezete döntéseinek függvényében alakult.

A kialakuló ınagyar földrajztudomány számála (egyrészt az államismereti irány túlsúlya, másrészt a bonyolult reálfolyamatok és közjogi felfogások miatt természetes módon vált kutatási feladattá a történetileg változó állam területi problematikájának feldolgozása. A magyar földrajztudomány állaınterülettel kapcsolatos kutatásai, törekvései és értékítéletei a köztörténeti folyamatok, az állanterület helyzete váitozásának függvényében többször átalakultak. A magyar földrajztudomány a dualizmus időszakában a „birodalmi tudat” egyik formálója volt, ınajd a két világhábolú között a telületi revíziós politika egyik meghatározó tudományos képviselőjévé vált.

1945-48 között a magyal földrajztudomány sok tekintetben korrigálta korábbi felfogását a magyar államtél'el kapcsolatban, de csak az erőszakos külső politikai és személyi beavatkozások után és eredményeként került sor alapvetö fordulatra.

A modern magyar fỏldrajztudomány kialakulásától 1948-ig egyfajta szerves, töıténeti kontinuitás figyelhető meg a földrajztudomány államtérrel kapcsolatos felfogásának változásában, s tanulmányunkban ennek érzékeltetését tekintjük elsődleges feladatunknak.

\section{A szomszédsági környezet történeti változása}

Közép-Európa államtörténete egyik meghatározó sajátossága, hogy a térség állaınai a „hatalmi libikóka” állásától függően térbelileg is gyakran és jelentősen változtak. A térség államhatár-állandósága (1. ábra) történetileg relatív, bár egyes határszakaszok stabilitása szembetűnő. A 20. század az államterületi átrendeződés szempontjából még mozgalmasabb volt minden korábbinál.

Az egész nagyrégiót szemlélve azt látjuk, hogy nagyon alacsony azoknak a területeknek az aránya, melyek kizárólag egyetlen állami szuverenitảs alatt élték meg történetüket, illetve tölténetük nagyobb l'észét. A tér szinte minden egyes darabjához többféle történeti kapcsolat, attitüd, nosztalgia, egyes esetekben nyilvánosan megfogalmazott területi igény társult.

Az államhatálok gyakori változása miatt és a feudalizmus évszázadai alatti, dinasztikus és bonyolult hübéli viszonyai következtében a térségben rendkivül összetettek a történeti közjogi kapcsolatelemek. A feudalizmus időszakában valamennyi ideig szinte 
A magyar államtér változásainak történeti és politikai földrajzi szemlélete a magyar földrajztudományban 1948-ig. Tér és Társadalom, 9. 1995. 3-4. 111-132. p.

TÉT 1995 • 3-4 A magyar államtér változásának történeti és politikai...

1. ÁBRA

Az államhatárok állandósága Közép-Európában, 1000-1920

(The stability of the state borders in Europe, 1000-1920)

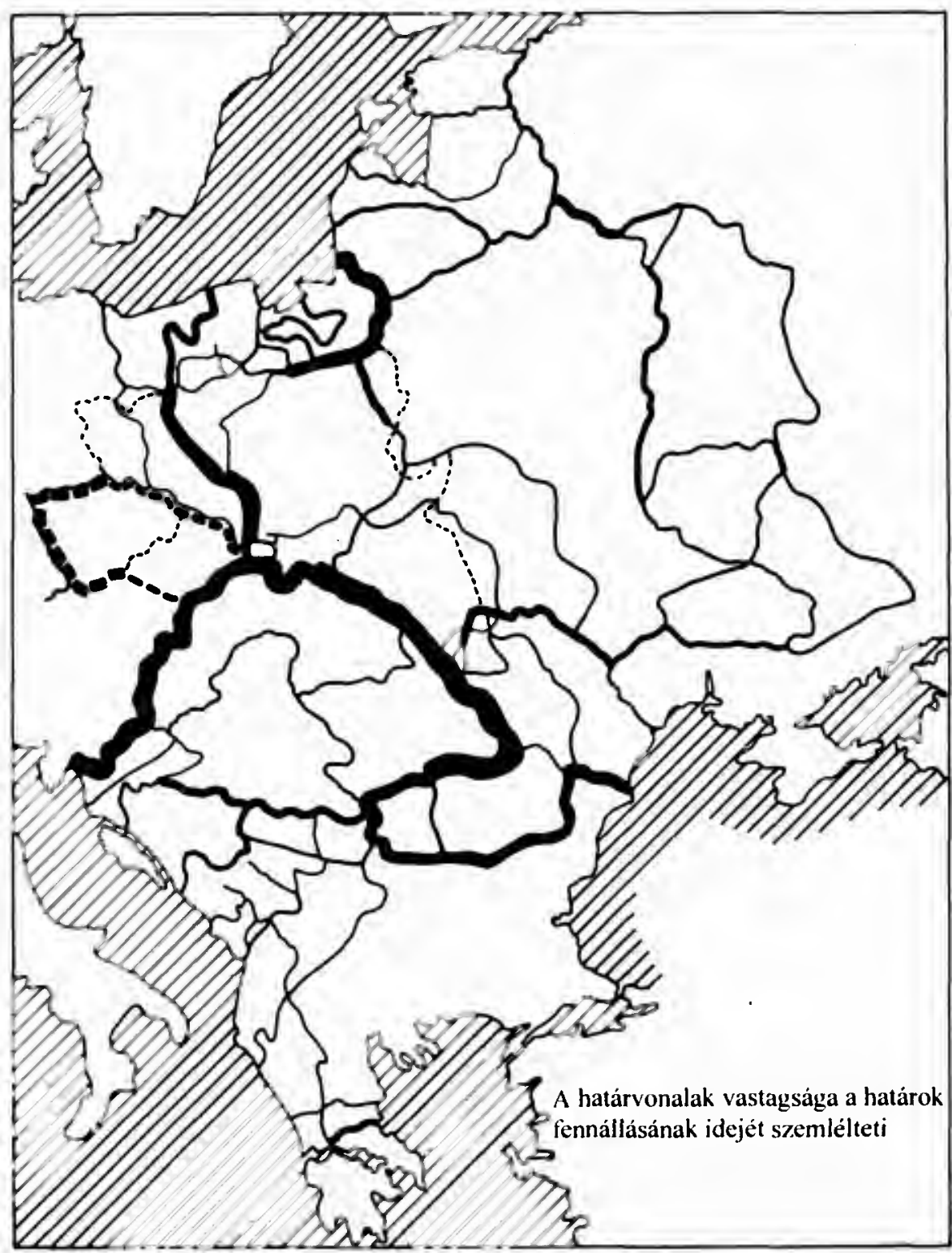

Szerk.: Rónai A. (1945) 
minden terület „ura és szolgája” is volt valamelyik szomszédjának. A 20. század két világháborúja és azok területi következményei szintén alapvetöen átrendezték az uralmi viszonyokat. Ezért történetileg és érzelmileg is bonyolult a területi kérdések hosszú időszakot átfogó elemzése ebben a térségben.

A magyar állam szomszédsági környezete a nagyrégió általános fejlödési tendenciáinak megfelelően történetileg folyamatosan változott és újrarendeződött. A változások egyik meghatározó állandó eleme, hogy története folyamán a magyar államnak mindenkor volt nagyhatalmi, esetenként világhatalmi szomszédsága, s részben ebböl a forgószínpadszerú együttélésből fakadt az államhatárok gyakori változása.

A magyar állam története első szakaszában, 1526-ig inkább energikus formálója, késỏbbi történeti pályáján pedig elsósorban elszenvedôje a nagytérségben lejátszódó folyamatoknak, hatalmi és területi átrendeződéseknek. A magyar állam 1526 után elvesztette önmeghatározó lehetőségeit és képességeit, fokozatosan alárendelödött környezete mozgáspályáinak. 1867 után alapvetően e tekintetben csak egyfajta korrekciós szakaszról beszélhetünk, bár a kortársak egy része a változásokat az újbóli nagyhatalmi státus jeleként értékelte.

\section{A magyar államterület történeti-térbeli fejlödése}

Az államtér változása az államalapitástól a független magyar állam bukásáig

A korszakot hagyományosan két idöszakra (Árpád-kor, vegyesházi választott királyok kora) tagolja a magyar történettudomány. Az államtér története szempontjából a tekintetben releváns e tagolás, hogy a „nemzeti monarchia” a megszerzett területeket „saját koronájához" csatolta, az Árpád-ház kihalása után a magyar trónért versengő dinasztiák esetében már felvetỏdött a magyar királyi cím és az ország területi egysége kezelésének mikéntje és közjogi kapcsolatának mibenléte (Marczali H. 1920, Donáth Gy. 1938).

A honfoglaló magyarság az elsö évszázadban a szomszédos országok és távolabbi területek felé eltérő tartalmú és sikerủ kalandozásokat folytatott, majd a stratégiai vereségek után fokozatosan minden irányban beszükültek a sikeres vállalkozások lehetöségei.

Az európai keresztény közösségbe beilleszkedö új magyar királyság eltérö jellegü és tartalmú (2. ábra) politikát folytatott a kủlönbözö stratégiai irányokban:

Nyugat-Európa felé a magyar királyság katonai erőkifejtése, illetve erökifejtésének hatóköre fokozatosan csökkent. (Ez leginkább a nyugati országhatárok visszavonásában követhetó nyomon: 913-ban az országhatár még az Enns, majd 1043-tól a Lajta és a Morva lett az ország határa). A magyar állam nyugat felé az együttmüködés szálait építette, hatalmilag azonban fokozatosan egyre inkább védekező pozícióba kényszerült. (Péter, Szent István közvetlen utóda, helyzetének belső megszilárdítása érdekében már 
A magyar államtér változásainak történeti és politikai földrajzi szemlélete a magyar földrajztudományban 1948-ig. Tér és Társadalom, 9. 1995. 3-4. 111-132. p.

TÉT 1995 -3-4

A magyar államtér változásának történeti és politikai...

115

\section{2. ÁBRA}

A magyar hatalmi tér alakulás a honfoglalástól 1526-ig

(The transformations of the Hungarian power relations from the

original settlement till 1526)

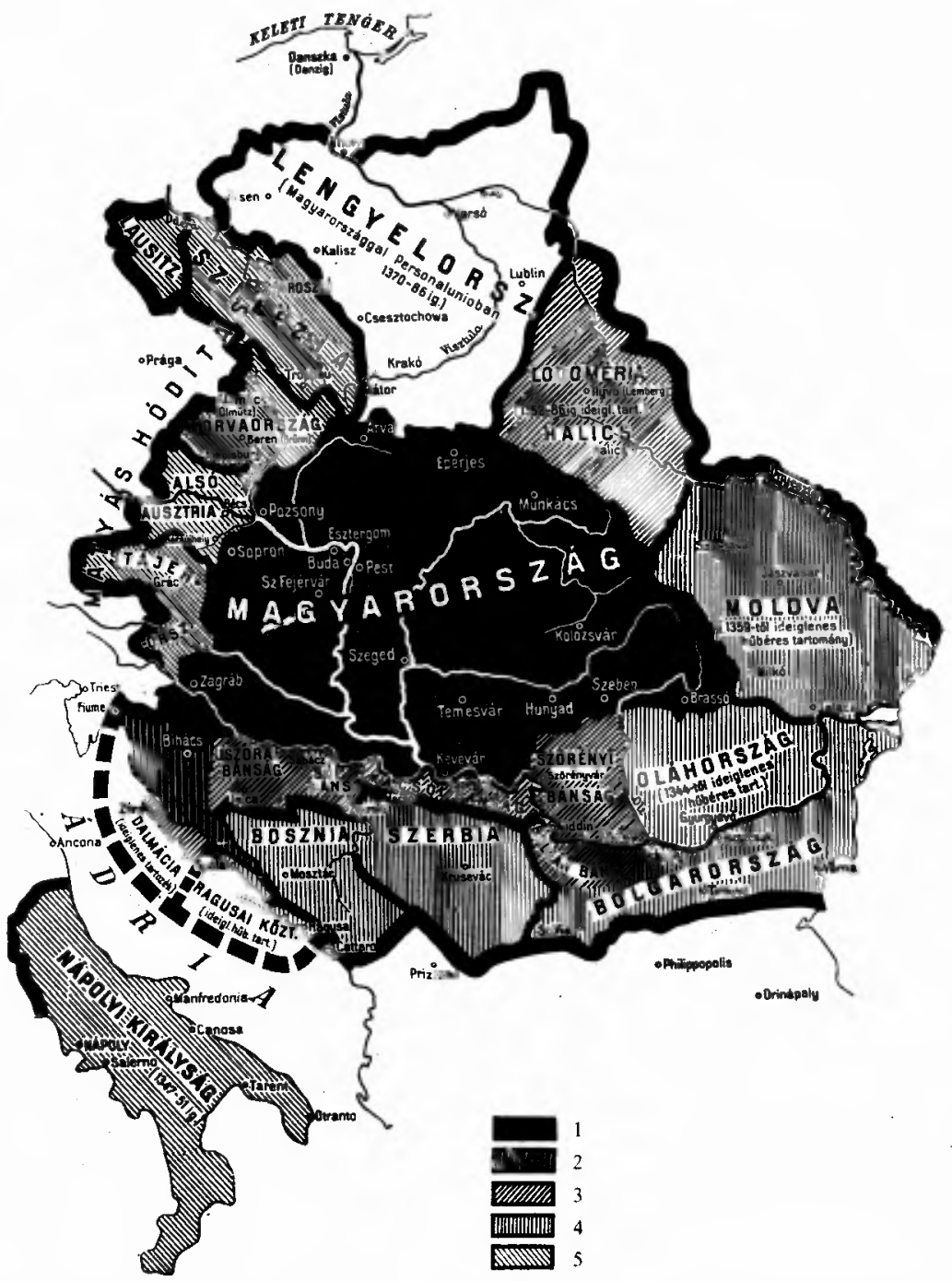

Jelmagyarázat: 1 - a m. szt. kor. ösi birtoka; 2 - Horvátország; 3 - a m. szt. kor. ideiglenes tartozékai; 4 -ideiglenes hủbéres tartományok; 5 -ideiglenes hódítások.

Szerk. Kogutowicz K.-Mákó J. (1920) 
hủbérurának ismerte el a német-római császárt, amit sem korának magyar vezetỏ rétege, sem pedig utódai nem fogadtak el).

Az északi, vagy lengyel politika viszonylag békés, de a lengyel uralkodók többször kísérletet tettek a Morva és a Vág völgyének megszerzésére. Az északi stratégiai irányban az együttmüködés és a rivalizálás egyaránt jelen volt, de hosszabb időszakot tekintve inkább az egymás mellett élés tekinthetỏ a meghatározónak.

A megalakuló magyar keresztény királyság északkelet felé inkább támadó, erejét érvényesítő képződmény, de igazán tartós hódításokat a Kárpátokon túl nem ért el, a szláv fejedelemségek belső trónviszályaiba beavatkozva könyvelhetett el viszonylagos sikereket. Halics és Lodoméria elfoglalása mindig csak időszakos jellegủ volt, ennek ellenére a magyar uralkodók felvették a „Halics és Lodoméria királya” titulust uralkodói címeik sorába (1187).

A keleti stratégiai irányban kifejtett törekvések többosztatúak. Erdély 1002-ben került Szent István uralma alá, amikor az erdélyi Gyulát legyőzte. Ez végül is egy, a magyar szállásterületet érintő „belső” küzdelem volt, de ettől kezdve egyfajta sajátos kapcsolt rész jellege maradt Erdélynek. Az erdélyi vajda mindenkor az uralkodó kinevezettje és személyes képviselöje volt a területen. Az etnikai betelepítésekkel (szászok) és betelepülésekkel (románok) Erdély sok tekintetben az ország etnikailag legsokszínübb, belsỏ közigazgatásában legbonyolultabb részévé vált.

A szélesebb értelemben vett keleti politika és terjeszkedés II. Endre nevéhez füzödött, aki a havaselvei hadjáratok után 1228-ban felvette a „Kunország királya” címet. A magyar állam a Kárpátokon túl ezen a részen sem volt képes érdekei hosszú távú érvényesitésére.

A déli irány és határ a kezdetektől a legnyitottabb, legbizonytalanabb és leginkább problematikus. A fiatal magyar államnak ebben a térségben meg kellett küzdenie az óriási történelmi tapasztalatokkal rendelkező Bizánccal. 1136-ban Bosznia meghódítása jelezte a magyar törekvéseket.

A kor értékrendje szerint a legsikeresebb a délnyugati stratégiai irányban kifejtett tevékenység. Magyarország Szent László, majd Könyves Kálmán uralkodásától kezdve a délnyugati stratégiai irányban kifejezett területszerzö politikát folytatott, s megkezdödött a kor szokásainak és nemzetközileg elfogadott technikájának érvényesítése mellett az államterület bővitése. 1089-ben Szlavónia, 1091-ben Horvátország került a magyar korona uralma alá úgy, hogy Kálmán 1102-ben felvette a „Horvátország királya” címet. 1105-töl megkezdődött Dalmácia meghódítása, $\mathrm{s}$ a terület feletti uralomért folyó több évszázados, váltakozó sikerú és szereposztású küzdelem.

III. Béla neveltetésénél fogva természetes módon használta fel és ki a bizánci politika eszközeit, s teremtette meg, illetve stabilizálta a „Magyar Birodalmat”, fogadtatta el azt a korabeli Európa egyik jelentós hatalmaként, ha nem is igazi „nagyhatalma"-ként. A déli stratégiai irányban utódai is folytatták a terjeszkedést, 1202-ben Imre felvette a „Szerbia királya” címet is. IV. Béla az 1241 -es tatárjárás vérveszteségei ellenére újrateremti a térségen belüli magyar középhatalmi alapállást, s megszilárdítja a kapcsolt 
részek függő helyzetét. 1254-ben már meghódítja Styriát, majd 1255-ben a „Bolgárország királya" címet is felveszi.

A ,nemzeti monarchia” utolsó szakaszában a magyar uralkodó címe (Magyarország, Dalmácia, Horvátország, Ráma, Szerbia, Galícia, Lodoméria, Kunország és Bolgárország királya) kifejezte a korábbi hódításokat, de a cím és a reálisan birtokolt tér már részben elvált egymástól.

A ,vegyesházi királyok kora” (1301-1526) a tértörténet és közjogi felfogás szempontjából azért érdekes és érdemleges, mert az Árpád-ház mint „nemzeti dinasztia” alatt kétség nélkül a magyar koronához rendelödtek a különböző meghóditott területek, s így a hübéri függések rendszere viszonylag egységes tartalmat kapott. Az 1301-töl 1526-ig tartó periódusban a „koronák közös bírása” egyszerre dinasztikus és „modern birodalomépítési törekvéseket" is hordozott már (Herczegh G. 1987).

$\mathrm{Az}$ Anjouk hatalmuk országon belüli megszilárditása után részben folytatták a délnyugati stratégiai irányban az évszázados ,nemzeti politikát”, s Velencével való küzdelmükben a dinasztikus és a térpolitika egyaránt megjelent. A Nápollyal kapcsolatos politika kizárólagosan dinasztikus jellegü, míg a Tengermellék megtartásában már megjelent a tengeri kijárat szükségességének a felismerése is. A magyar-lengyel perszonálunió nem járt a két terület erőforrásainak egyesítésével, valójában csak Nagy Lajos személyére szabott kapcsolat volt. (A Nagy Lajos-féle magyar birodalom, ,a három tenger mosta Magyarország" elemzése és ábrázolása szerves részévé vált minden történeti földrajzi monográfiának, $s$ késöbb iskolai tankönyvnek). A török elörenyomulásával az 1375-ös évtól kezdve a délkeleti húbéres tartományok uttközô zónává váltak Nagy Lajos birodalma és a török birodalom között.

A magyar állam szempontjából a 15 . század egésze a változó eredményü, de stratégiai gyözelemmel és vereséggel nem járó küzdelem a törökkel. Zsigmond látványos nemzetközi pályafutása (német-római császári címe) nem járt közvetlen eredménnyel a török elleni harcokban.

Az államtér és az uralmi tér szempontjából rendkivül fontos elemet jelentettek az ún. „elzálogosítási ügyek”. A mindenkori uralkodó hatalma megszerzése vagy megtartása, anyagi erőforrások előteremtése céljából az ország egy-egy részét, várát idegen államok zálogába adta. (A szepesi XIII város lengyel zálogba került (1412), s mint ilyeneket az ország részének tekintették ugyan, de nem tekintették magyar közigazgatás alatt álló területnek, így pl. az 1720-as összeirás alkalmából nem is vették számba. A zálogba adott városok csak 1772-ben kerültek vissza a magyar koronához.)

Hunyadi Mátyás rövid ideig tartó tudatos, erőkoncentráló uralma és politikája látványos területi hódításokat hoz nyugaton, de a déli területeken korántsem annyira eredményes tevékenysége. Mátyás „személyhez kötött magyar birodalma” (Magyarország, Csehország, Dalmácia, Horvátország, Ráma, Szerbia, Galícia, Lodoméria, Kunország és Bulgária királya, Szilézia és Luxemburg hercege, Morvaország és Lusitza örgrófja) rövid életü volt, nem vált szerves politikai-uralmi térré. A Mátyás-féle 
birodalom megjelenítése szintén a történeti földrajzi folyamatok elemzésének alapeleme lett. (A magyar nemesség megkísérelte ugyan Mátyás hódításainak egy részét a ,korona birtokában" tartani a későbbiekben is, ezért II. Ulászlót kötelezte arra, hogy Morvaország, Szilézia és Lausitz az ország koronájától el nem idegenítendö [1492. 4. tc.], de e törekvése nem járt eredménnyel).

Werböczy „Hármaskönyve” (I. kiadása 1517-ben jelent meg) mindenre kiterjedöen lerakta a magyar nemesi jogszemlélet és szokásjog alapjait. II. Ulászló címeként megismételte a Mátyásnál már említett területeket és szóhasználatában „egész Magyarországon és az ebbe bekebelezett tartományokban és alája vetett részekben” (75. o.) mindvégig érzékeltette a magyar területi struktúra összetett, birodalmi jellegét.

A III. részben foglaltak világossá tették, hogy Werböczy különbséget tett a tényleges és a ,rituális" államterület között. A tényleges államteret korlátozottabban szemlélte, mint a történeti fejlödés során kialakult közjogi konglomerátumot: ,....Magyarország szent koronájának régen alája vetett és abba keblezett országoknak, tudniillik Dalmát-, Horvát- és Slavonországnak és Erdélynek..." tulajdonított gyakorlati jelentőséget (375. o.). A területi struktúra megfogalmazásakor a „magyar birodalom” szúkebb, de a korszakban itthon és külföldön is elfogadott képét rajzolta meg.

A szentkorona eszme közjogi megfogalmazásakor a terület problematikája már világosan megjelent, de nem képezte az elmélet alapját (Eckhart F. 1941). Az államterület késóbbi jogi és közjogi szemlélete elsősorban a szentkorona tanra támaszkodott, annak szellemében fogalmazta meg az ország történetileg változó területi struktúráját, illetve a különböző területekhez kötődö kapcsolatokat (Molnár K. 1929, Tomcsányi M. 1942).

\section{A megosztott államtér problémái}

Az 1526-1686 közötti történeti folyamatok a „,megosztott és pulzáló államtér" fogalmával jellemezhetöek történeti és politikai földrajzi szempontból. Az ország két-, majd három részre szakadása, s a ,részek küzdelme" sok tekintetben új és fájdalmas szakasza a magyar állam- és térfejlödésnek.

A korszak elején a török, idöszakosan az erdélyi fejedelemség, a korszak végén pedig a Habsburg-ház volt a folyamatok elsödleges meghatározója. A török hadsereg (pl. a két Bécs elleni hadjáratban) többször elvágta a királyi Magyarország, a korábbi egész országọt tekintve, „szegély”-jellegű területeit egymástól. Az erdélyi fejedelemség a török hatalomtól fưggő terület volt, de időnként önálló nagypolitikai szereplövé és térformálóvá vált (3. ábra).

A három részre szakadt országban is megmaradt az államegység egyfajta tudata, $\mathrm{s}$ méginkább igénye. Ezt az igényt a magyar nemesség és lakosság mindhárom részországban megórizte, ha némileg más tartalommal is, de hordozta a történeti múlt és a jövő államát. A, Két pogány közt egy hazáért” ideológia mély gyökereket eresztett, de történetileg a „kényszerválasztás” adatott a korszak szereplőinek. 


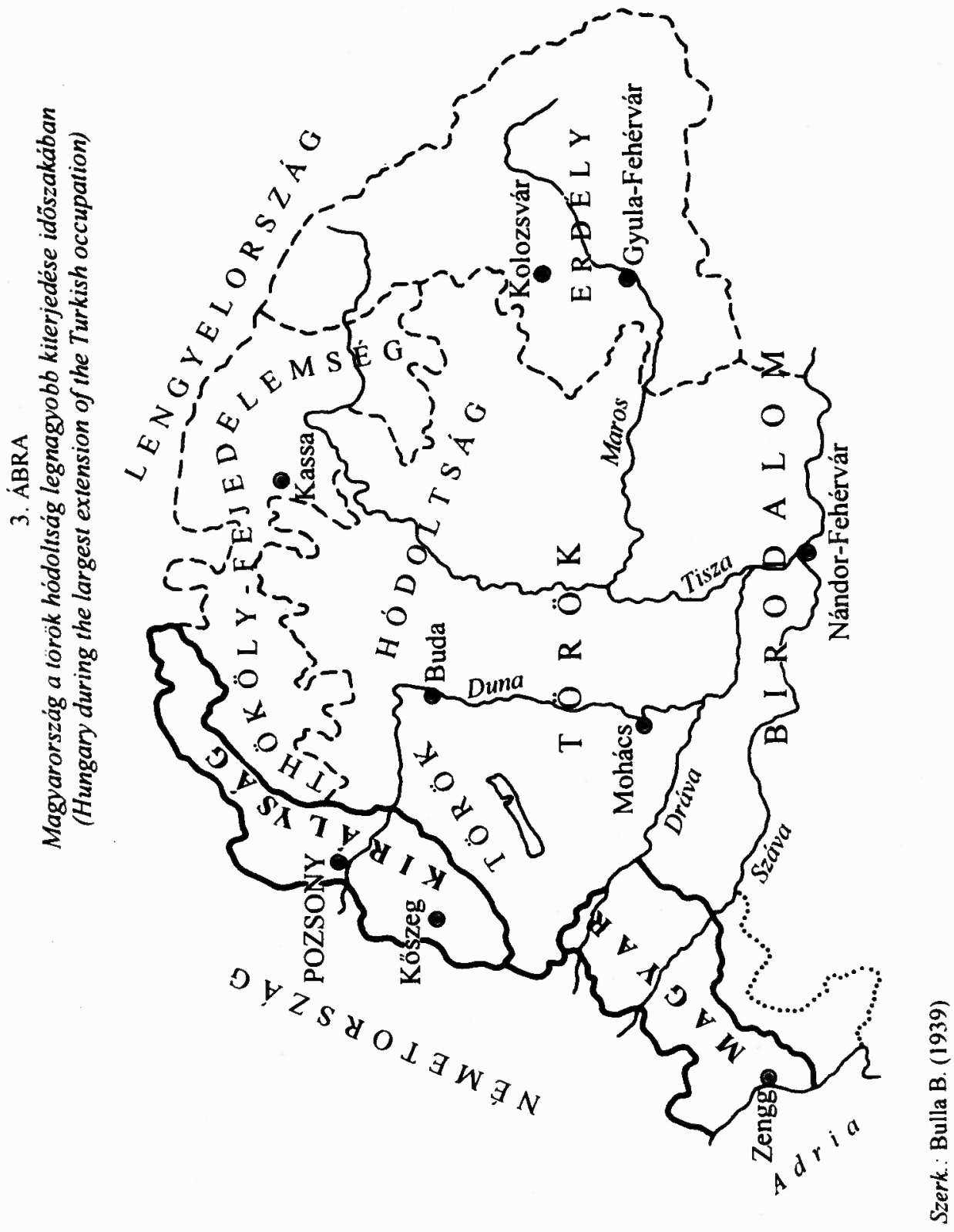




\section{A Habsburg hatalmi térbe integrált magyar államtér (1686-1918)}

A tơrök alóli felszabadító háborủ után az ország korábbi történeti-területi egységét a gyöztes Habsburgok nem állították helyre, pedig a magyar nemesség Buda felszabadítása felett érzett örömében alkotmányosan elfogadta a fiágon örökletes monarchiát, majd 1723-ban a leányági örökösődés elvét is. A bécsi udvar saját érdekú gazdaság-, etno- és térpolitikát érvényesített, s a felszabadított területeket, mint „új szerzeményeket" tekintette. Erdély önállóságát fenntartották, de a korszak legsajátosabb térképződménye a közvetlenül a Haditanács alá tartozó katonai határörvidék létrehozása volt. Az ország teljes déli határa mentén létrejött egy biztonsági-katonai sáv, mely kezdetben valós védeimi elemet hordozott, később azonban az ország gyengítésének és etnikai összetétele megváltoztatásának egyik eszközévé vált.

Az 1720/21-es összeírások (Acsády I. 1896) egy tudatosan szétdarabolt történeti államerületet regisztráltak: anyaország, az anyaországhoz tartozó katonai uralom alatt álló területek, az önálló erdélyi fejedelemség, majd nagyfejedelemség, Horvát- és Szlavónország és a hozzá tartozó katonai határörvidék.

A „közigazgatásilag szétdarabolt történelmi államtest” tudatos fenntartása a történeti magyar állameszmény megtörését szolgálta, de a nemzeti ébredés idöszakában a magyar nemesség felismerte ennek jelentöségét és tudatosan követelte az állam területi egységének helyreállítását.

Az 1848-as forradalom követelései között kitüntetett helyen szerepelt az unió a „két magyar haza", Erdély és Magyarország között. A forradalom leverése után az államtér „Szabdalása" ismét politikai céllá és egyben a magyar társadalom megfélemlítésének eszközévé vált (Edelényi-Szabó $D$. 1928).

Az 1867-es kiegyezési törvény alapján Ferenc Józsefet „Magyarország és Társországai királyá"-vá koronázták és kompromisszumos jelleggel szabályozták a „magyar korona országai és az Ö Felsége uralkodása alatt álló többi országok között fennforgó közös érdekü viszonyokat", de anélkül, hogy pontosan meghàtározták volna, hogy az egyes kategóriákon térbelileg mit értenek.

Az 1868-as magyar-horvát kiegyezési törvény Magyarország és Horvát-, Szlavón- és Dalmátországok közjogi és igazgatási viszonyait rendezte. A törvény kimondta, hogy „Magyarország s Horvát-, Szlavón- és Dalmátország egy és ugyanazon állami közösséget képeznek...”. Az államterület egységes, államhatárai csak a magyar államnak vannak, a Magyarország és a társországok közötti határ közigazgatási jellegü.

A törvény tételesen felsorolta azokat a területeket, melyeket a társországok területéhez tartozónak ismert el. (A gondot az jelentette, hogy Dalmácia ténylegesen osztrák igazgatás alatt álló tartomány volt, ezért olyan kitételek is bekerültek a törvénybe, melyek „Dalmatia tettleges visszacsatolása” utáni következményekkel is számoltak). Magyarország lemondott a tỏrténeti Alsó-Szlavóniáról a horvátok javára, ugyanakkor Fiume ügyében nem sikerült megegyezni, így az ideiglenesen a magyar koronához csatolt „,ülön test lett”, $s$ ezt a státusát a dualizmus egész időszakában megtartotta. 
Az 1878-as berlini kongresszus határozatai alapján a Monarchia megszállta és pacifikálta Boszniát és Hercegovinát. 1908-ban a két tartományt annektálták a Monarchiába, s az 1910. februári rendelkezésekkel a két tartomány önkormányzatot kapott s Bosznia és Hercegovina lényegét tekintve osztrák-magyar közös tartomány (condominium) lett (4. $a ́ b r a)$. A magyar kormány a tartományokhoz való viszonyt az ország címerében is megjelenitette, amikor 1915-ben a két tartomány címerét beillesztette a magyar állami középcímerbe.

Románia katonai veresége után 1918-ban megtörtént a kárpátoki magyar-román határ „kiigazítására”, melynek során $3772 \mathrm{~km}^{2}$ terület és 42 falu 22915 fövel került Magyarországhoz (Olay F. 1930).

\section{A szuverén magyar állam térbeli változásai (1918-1947)}

Az I. világháborús vereség után a Monarchia részben belső etnikai feszültségei, alapvetően azonban a gyöztes nagyhatalmak korábbi döntései nyomán felbomlott. A változások érintették a Monarchia mindkét részét. A töıténeti Magyarország (5. ábra) korábbi területének $\left(325411 \mathrm{~km}^{2}\right)$ töredékével $\left(93\right.$ ezer $\left.\mathrm{km}^{2}, 28,6 \%\right)$ és a korábbi népességszámok (20,8 millió fö) úgyszintén csak kis részével (7,6 millió fó, $36,5 \%)$ került ki a világháborús kataklizmából.

Sem a magyar politika, sem pedig a magyar társadalom és tudomány nem tudta megemészteni ezt a tragikus struktúraváltozást. Részben azért nem tudta tudomásul venni, mert az államhatárok megvonásakor a gyöztes hatalmak saját megfogalmazott értékeikkel szemben húzták meg az ország új határait, s a magyarság egyharmad részét leválasztották az új államterületrool.

A 11. világháború elött és alatt elsösorban a világpolitikai váttozások és kompromisszumok nyomán megváltoztak az ország trianoni határai (1938 - I. bécsi döntés, 1939 - Kárpátalja, 1940 - 11. bécsi döntés, 1940 - Délvidék). A változások nyomán Kárpátalját leszámitva - magyar etnikai többségủ területek kerültek vissza az országhoz.

A fegyverszüneti egyezmény aláirása (1945. I. 20.) már elörevetítette, hogy a háborús vereség után az ország nem tudja megtartani a világháború elött és alatt megszerzett térségeit, bár egyes területek megörzésére történtek tétova kísérletek a párizsi béketárgyalások elött és alatt.

Az 1947-es párizsi békeszerződés végül is a trianoni határokat szavatolta ismét, azzal a nem elhanyagolható különbséggel, hogy Pozsony védelme érdekében a „Pozsonyi hídfö" három községe Csehszlovákiảhoz került (Rónai A. 1947). 


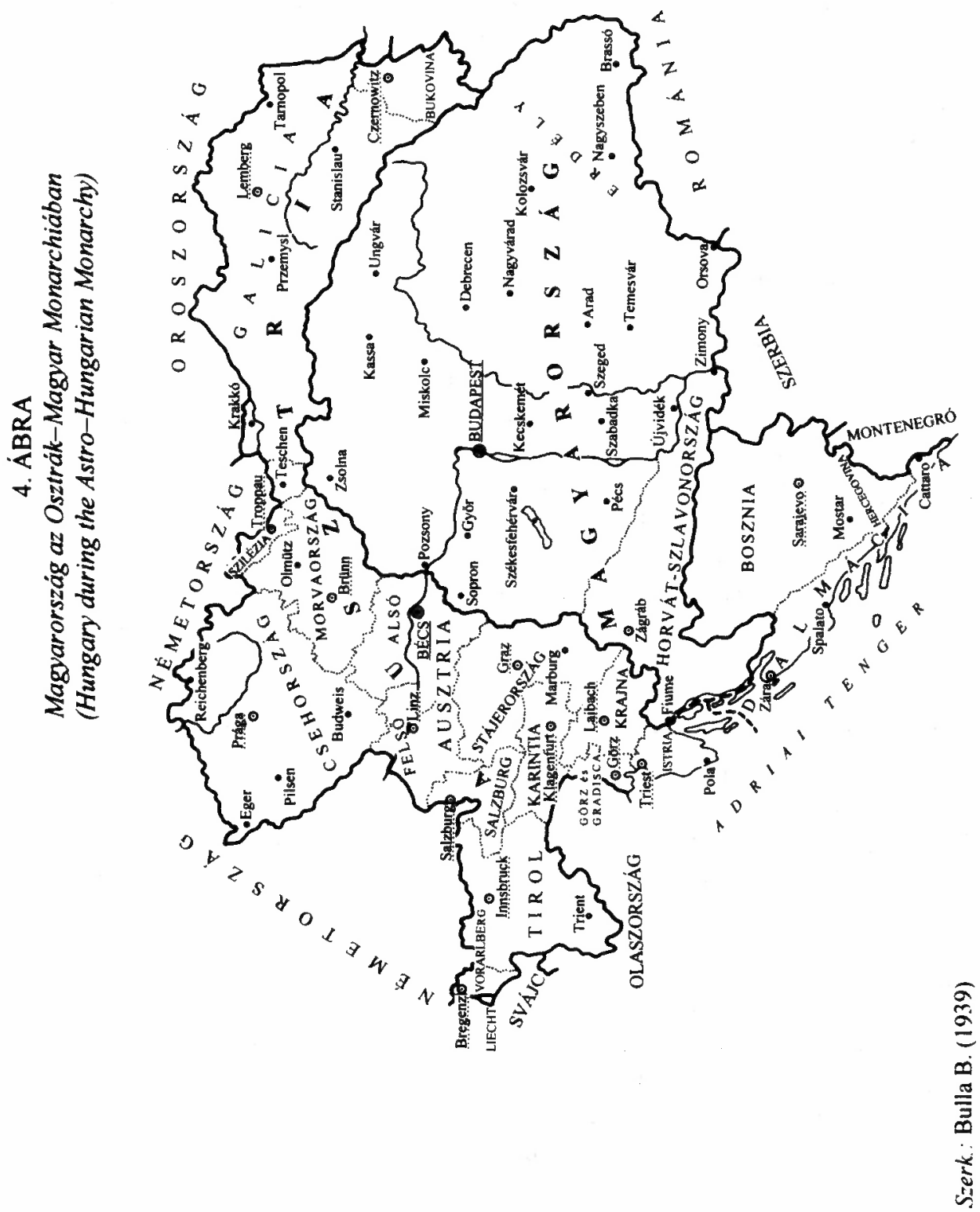


A magyar államtér változásainak történeti és politikai földrajzi szemlélete a magyar földrajztudományban 1948-ig. Tér és Társadalom, 9. 1995. 3-4. 111-132. p.

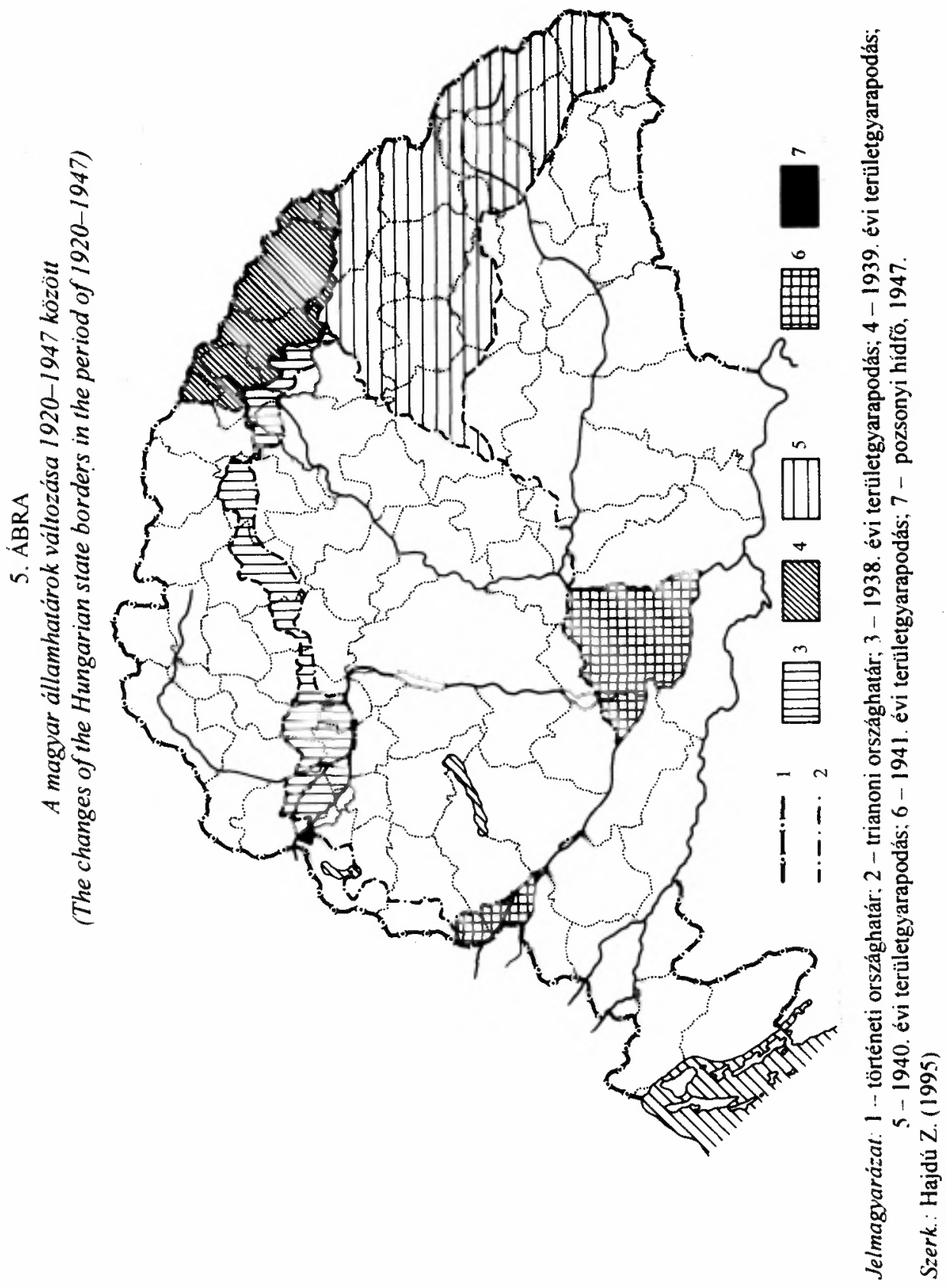




\section{A magyar földrajztudomány államtér szemlélete}

A magyar földrajztudomány története a 18. századtól kezdve a legtöbb tekintetben követte a nemzetközi fejlödési tendenciákat (Fodor F. 1949/1951). Témánk szempontjából elsősorban a történeti, politikai és statisztikai jellegü államismereti irány érdemel figyelmet. Ez az irányzat elsösorban az állam igényeit volt hivatott kielégíteni, így alkalmazkodott is hozzá.

Bél Mátyás (1684-1749) a hazai történeti földrajz megalapítója, az ország fôldrajzi szemléletének első megfogalmazója. 1735-ben megjelent latin nyelvü „Notitia”-jában fektette le az ország közjogi struktúrája földrajzi szemléletének és regionális felosztásának, valamint tárgyalásának alapjait (Bél M. 1735). A több kiadásban megjelent „Compendium"-ban, Magyarország latin nyelvü földrajzában (1792a) az általános részben a történeti-közjogi terület felsorolása (Croatia, Dalmatia, Rama, Servia, Gallicia, Lodomeria, Cumania, Bulgaria) mellett a ,szükebb értelemben vett, tényleges" Magyarországot elemezte. Másik munkájában (1792b) részletekbe menően dolgozta fel „Croatia, Slavonia, Dalmatia" valamint „Gallicia, Lodomeria” és „Transilvania” földrajzát.

Hivatkozásainak döntö része közjogi, történeti jellegü. Bél mindenekelött saját korának állapotait mutatja be, de tudatosan történeti és közjogi folyamatba ágyazva tárgyalja azokat. A földrajzi elemzés területi rendjét meghatározza a közjogi-történeti szemléletre támaszkodó államismereti igény.

Szászky Tomka János (1700-1762) latin nyelvü „világleíró” monográfiája rendkívül érdekes, hiszen a nemzetközi földrajzi feldolgozások ismeretében és nyomán egyeztetnie kellett a Magyarországra vonatkozó felfogását részben a „nemzetközi tudományossággal”, részben pedig a magyar történeti-közjogi felfogással, és állást kellett foglalnia az ország tagolását illetően. Egy fejezetben, de elkülönített részenként tárgyalta Magyarország, Galícia, Lodomeria, Erdély és az 1 llir Magyarország földrajzát. Magyarország leirása után dolgozta fel Galíciát és Lodomériát, majd az erdélyi nagyfejedelemséget, $s$ végül Szlavóniát, Horvátországot és Dalmáciát tárgyalta.

A földrajzoktatás számára első kiadásban 1770-ben megjelent Losontzi-féle „Hármas Kis Tükör" csak a szükebb értelemben vett Magyarországot jelenitette meg a diákok elött, attól elkülönítve tárgyalta „Erdély Ország” történetét és földrajzát. A történeti felsorolásban jelent csak meg „Nagymagyarország”, földrajzi tekintetben nem értelmezte (Losontzi I. 1795).

A magyar nyelvủ földrajzi szakirodalom Magyarország képe már megjelenésekor rendkivuul fontos szemléleti alapokat rakott le. A formálódó nemzeti szellem jegyében fogalmazta meg: „Egész Európában leg-gönyörüségesebb, 's leg-kedvesebb Ország, ha Fekvését, és Termékenységét szemléllyük, Magyar Ország. Leg-alább meg nem írígyli ez más Tartománynak se Egét se Földét; olly kegyes és szelíd az ő Ege, 's bö termékeny Földe." (Szaller Gy. 1796, 2. 0.).

A magyar földrajz történeti szemléletét a kezdetektöl fogva a történeti államtér jelentöségének kiemelése jellemezte: „XIV. és XV. Században 9. Országokat kormány- 
zott a, Magyar Kormányszék, t. i. Magyar, Tót és Horvát Országokat, Rámát, Szerviát, Gallitziát, Lodomeriát, 's 'a Kun és Bolgár Országot mellyek egygyütt a közép Idöben Nagy Magyar Országnak hívattattak." (Szaller Gy. 1795, 4. o.).

A „Nagy Magyar Ország” vagy a „Magyar Birodalom” fogalma ettől a definiálástól kezdve többféle tartalmat kap (egyrészt egyszerüen csak teruletnagyságot jelent, másrészt jogi-funkcionális tartalmat kap, nevezetesen, hogy eltérö jogállású teruletrészekböl áll), de van egy közös elemük a késöbbi meghatározásoknak: szinte mindig nagyobb területet öleltek fel, mint az éppen ténylegesen magyar uralom alatt álló teruletek.

A 18-19. sz. fordulojától megjelenő új államismereti, statisztikai, földrajzi irodalom (Vályi A. 1796, Schwartner M. 1809, Magda P. 1819) elsösorban saját kora területi problematikáját elemezte, de kialakult egyfajta nosztalgikus visszautalás a magyar állam „régi dicsöségére”. Különösen Schwartner német nyelvú munkájában jelent meg a külföldi fôldrajzi irodalom Magyarországra vonatkozó ismertetése és egyben kritikája, nevezetesen, hogy rendkívül nagy eltérések vannak az ország közjogi struktúrája felfogását és területi nagyságát illetően.

A magyar „átigazitásban" megjelent külföldi enciklopédia (Galletti, J. G. A. 1844) rendkivül nehézkesen adta vissza fogalmilag a magyar államtér történeti és aktuális rendjét, és sokféle értelemben és kiterjedésben használta az egyes térkategóriákat és fogalmakat.

Fényes E. még a feudális kor végén is arról értekezett, hogy Magyarország térfogalma rendkívül bizonytalan, az adatok sok tekintetben ellentmondásosak, mert különbözö értelemben használták az ország fogalmát. Legszorosabban véve csak az anyaországot értették alatta, szoros értelemben már hozzá sorolták Horvát-Szlavónországokat, $s$ tágas fogalmába már beletartozott Erdély is. Legtágasabb értelemben mindazokat a tartományokat értették Magyarország alatt, melyek hajdan a magyar koronához tartoztak: „Legtágasabb értelemben a magyar birodalmat e következő országok képezik: Magyarország, Dalmatia, Horvátország, Tótország vagy Slavonia, Bosnyákország vagy Ráma, Ráczország vagy Servia, Havasal- és felföld vagy Oláh- és Moldvaországok." (Fényes E. 1847, 3. o.).

Történeti földrajzi szempontból az „Anyaország” térfogalma változott a legtöbbet. A török alóli felszabadulástól kezdve 1918-ig legalább hatféle területi értelemben jelent meg az Anyaország, mint olyan, majd 1920 után a trianoni Magyarországot kezdték el „Anyaország”-nak tekinteni, ezzel új területi és funkcionális tartalmat tulajdonítva a fogalomnak.

A modern magyar földrajztudomány az 1850-es évektöl elemi erővel szembetalálta magát az ország helyzetének, térfogalmának „önmaga”, a kutatás és az oktatás számára való megfogalmazási kényszerével. Hunfalvy János a Magyar Birodalom természeti viszonyainak leirása kapcsán (Hunfalvy $J$. 1863) áttekintve az államtest közjogi és történeti fơldrajzi problémáinak korábbi hazai és külföldi irodalmát nyugtázta, hogy a „Magyarbirodalom” térfogalma történetileg bizonytalanul, sőt eltéró tartalomban jelent meg mind a hazai mind pedig a nemzetközi földrajzi irodalomban. A birodalom 
kiterjedésének meghatározásában óriási különbségek léteztek. Az eltérések jelentős részben abból származtak, hogy a külföldiek nem minden tekintetben értették a magyar politikai tér tagolódását, $\mathrm{S}$ nem ugyanazt értették a „Magyarország a legszorosabb értelemben", a "Magyar Birodalom Erdély nélkuil” és a „Magyar Birodalom Erdéllyel" térbeli kategóriák alatt.

Hunfalvy az 1860-as évekre vonatkozóan is kénytelen a "tettleges magyar birodalom" és az „egész birodalom" tekintetében elemezni, hiszen saját korában is szétdarabolt volt a történetileg felfogott magyar államtér, mégpedig a központi osztrák kormány érdekeinek megfelelöen. Ugyanakkor fontos számára a történetileg kialakult „Magyarbirodalom” kategória továbbörökítése, hiszen ezzel is az ország egyenjogúságáért küzd.

Az 1867-es kiegyezés után megjelenó hivatalos statisztikai kiadványok fogalomhasználata az államteret illetỏen eltérỏ és következetlen. Használatos mind a „Magyarbirodalom”, mind pedig a „Magyar Korona Országai”, valamint a „Szent István Korona Országai" megjelölés.

A külfoolldi földrajzi irodalom és kartográfia egy része még a 20. sz. elején sem értette, illetve érvényesítette a kiegyezés után létrejött dualista állam struktúráját a térképi ábrázolásban. Magyarország sokszor Ausztria részeként jelent meg, helyzetét úgy ábrázolták, mint Bajorországét Németországon belül. (A Földrajzi Közlemények nyomon követte ezeket a kuilföldi „elnézéseket”, pl. 1906, 130. o.). Még a német földrajzi népszerüsitó irodalom is torz módon fogalmazta meg az osztrák-magyar közjogi és területi viszonyt (Ritter, A. G. 1909).

Havass Rezső a „birodalmi magyar gondolat” legnagyobb hatású földrajzi propagandistája és részben formálója egész tevékenysége középpontjába a Balkán és Dalmácia kutatását állitotta. Havass felfogása szerint a „magyar impérializmus” természetes és történeti terjeszkedési iránya a Balkán. Dalmáciával kapcsolatban folyamatosan azt vallotta, hogy „Dalmáczia nemcsak a történelmi jog, hanem az éló törvény alapján is Magyarország egyik országa" (Havass R. 1906, 39. o.).

A dualista politikai struktúra trialistává (osztrák, magyar, délszláv) átalakításának lehetóségei kiváltották a magyar földrajztudomány reagálását is (Havass $R$. 1909). Havass történeti és földrajzi szempontból egyaránt elutasitotta a Monarchia teruleti és hatalmi struktúrájának átalakítását.

Prinz Gyula 1914-ben - az ország elsỏ modern földrajzi monográfiájában - sajátosan fogalmazta meg az Osztrák-Magyar Monarchia földrajzi struktúráját: „A magyar birodalom és az osztrák birodalomnak uralkodója egy, ennélfogva e két birodalom együttesen alkotja a Magyar-Osztrák Monarchiát. A Monarchia két állama szövetkezett közös védelemre és az idegen államokkal szemben közös fellépésre, $s$ így földrajzi értelemben szövetséges államok. A Magyar-Osztrák Monarchia az egyetlen állami szövetség, melynek államai gazdaságilag és nemzetileg különbözőek..." (Prinz Gy. 1914, 159. o.).

Prinz e tekintetben továbbvitte Hunfalvy örökségét, a „Magyarbirodalom” birodalmi jellegét az osztrák birodalommal való egyenjogúságában fogalmazta meg, söt Prinz úgy 
ítélte meg, hogy a Monarchia súlypontja Magyarország, amit azzal is ki kell fejezni, hogy az uralkodó székhelyét Budapestre kell áthelyezni, s a Monarchiát a valóságos eröviszonyainak megfelelően „Magyar-Osztrák Monarchiả”-nak kell nevezni.

A magyar államtér bonyolult belső struktúrával bír Prinz szerint: „A magyar birodalom ma a birodalom törzséböl, Fiume a törzshöz csatolt kủlön testböl és HorvátSzlavónország társországokból áll. Jogilag társországa Dalmácia is, e tartomány azonban tényleg az osztrák állam tartozéka. A magyar és az osztrák államok közös társországa Bosznia-Hercegovina..." (Prinz Gy. i. m. 168. o.). Nemcsak közjogi, de földrajzi szempontból is sok negativ eleme van Prinz szerint ennek a bonyolult struktúrának.

A Magyar Földrajzi Társaság által évtizedekig sürgetett magyar és idegen nyelvü országismertetö mú az I. világháború végén jelent meg, így eredeti célját, nevezetesen a külföld objektív tájékoztatása, már nem érhette el (Lóczi Lóczy L. szerk. 1918). A mü a kor felfogása szerinti teljes magyar politikai térröl kívánt áttekintést adni. A közjogi felfogásnak megfelelően a Magyar Korona Országait három egységbe (Anyaország és Fiume, a Társországok, Bosznia és Hercegovina) sorolva. A részletes tárgyalás során különbséget tettek a Társországok között, Horvát-Szlavonország, mint csatolt, Dalmátország mint nem csatolt Társország került elemzésre.

A Magyar Földrajzi Társaság 1918-as „Szózata” (Anon. 1918) visszafogottabb a politikai tér meghatározásakor, már csak az anyaország jelenik meg megörzendö egységként, bár említi a „Szózat” Horvát-Szlavonországokat, de ezek elszakadásával már mint realitásként számol.

A háborús vereség „elöszelekor” a Teleki Pál által létrehozott Békeelökészítő Iroda megkezdte a béketárgyalásokra való tudományos felkészülést. A magyar békedelegáció tudományos és politikai tevékenységében egyszerre jelent meg a korlátozott államtér védelme (a delegáció sok elökészitő iratában szerepelt „Horvátország leválásának elismerése”, annak tudomásul vétele, hogy „Horvátország, amelynek különállósága többé kérdésbe nem jöhet" [Cholnoky $J$. szerk. 1920. I. köt. 21. o.]), valamint a teljes, történeti Magyarország problematikája.

$\mathrm{Az}$ iroda tevékenységének lett az eredménye a történeti Magyarország gazdasági, társadalmi, politikai struktúráit szemléltető atlasz (Edvi-Illés A.-Halász A. 1921), Magyarország gazdaságföldrajzi térképe (Fodor $F$. 1920) és az ország első modern gazdaságföldrajzi monográfiáaja (Fodor F. 1924).

A két világháború közötti magyar földrajztudomány államtérszemléletét döntően a történeti Magyarország eszményítése, $\mathrm{s}$ a területi revízió tudományos támogatása határozta meg. Egyes tanulmányokban megjelent „Csonkamagyarország” önálló tudományos feldolgozása is, de lényegileg minden geográfus a történeti Magyarországban gondolkodott valamilyen megközelítésben.

Teleki 1918-tól már mint tényt könyvelte el Horvátország leszakadását, s csak az Anyaország területének kutatására koncentrált érdemben. Híres néprajzi térképe a "Carte rouge" is csak az Anyaország területét ábrázolta már. 1921-ben kifejezetten az 
Anyaország területét osztotta fel - már annak szétdarabolása után - új, tájkőzigazgatási egységekre (Teleki P. é. n. [1934]).

Az 1920-as évektöl kezdve szinte a teljes magyar földrajztudomány a tájelméletre építette tơrténeti és politikai fỏldrajzi elemzéseit, hiszen a táj volt az a nemzetközi földrajztudományban széles körben elfogadott térkategória, melyre támaszkodva nagyobb eséllyel lehetett a revíziót szolgálni.

Az Egyesült Államokban tartott angol nyelvủ elöadásaiban Teleki minden korábbinál tudatosabban fogalmazta meg a tájegység-államegység harmóniáját a történeti Magyarországra vonatkoztatva, $\mathrm{s}$ az ország történeti-térbeli fejlödésének folyamatát és hatalmi pozícióinak elsősorban a külsó hatások nyomán történő folyamatos újrarendeződését (Teleki P. 1923).

Fodor térszemléleti kiindulópontja a teljes két világháború közőtti magyar földrajztudomány alapállását és térszemléletét jellemezte azzal, hogy megfogalmazta: „Könyvem egész fonalán mindvégig a csonkítatlan Magyarországgal foglalkozom... Csonkamagyarország gazdasági földrajzának megírása önmagában való ellentmondás." (Fodor F. 1924, 9 o.)

Az 1930-as években Prinz már szakítani kíván mind a történeti, mind pedig a politikai uralmi területekkel, s a magyarság természetes fỏldrajzi hazáját kívánja meghatározni: „,... a kiszabott terủlet, amelyröl ez a mü szól, nem politikai uralmi terület, nem történelmi regnum és nem politikai törekvés eszményi országa...”, hanem „...hideg tárgyilagossággal csak egy földrajzi országot kutatunk, a magyarság földjének országát...”. A természetföldrajzi keretek felértékelése jelent meg abban, hogy: „Az összes, mindenfajta határvonalak szintéziséböl merítjük ki egy természeti tájegység határvonalát, azután pedig bemutatjuk, hogy meddig ér benne a magyarság, meddig töltötte azt ki és meddig alakította ki magyar földdé." (Prinz Gy.-Teleki P.-Cholnoky J. é. n. I. kötet, 10. o.)

Cholnoky Jenõ politikai és tudományos állásfoglalása így hangzott: „Az egész könyvön végig „hazánk” elnevezéssel illetem a történelmi Magyarországot. Nem ismerjâk el a megcsonkítás jogosultságát és észszerüségét, $s$ kétségtelennek tartjuk, hogy az ezeréves Magyar-Birodalom előbb-utóbb ismét helyre fog állni, mert ezt a fôldrajz kérlelhetetlen törvényei követelik" (Cholnoky J. é. n. [1937] 7 o.).

Az 1930-as évek közepétöl publikáló Rónai András elméleti, elmélettörténeti elemzések után helyezkedik arra az álláspontra, hogy ebben a térségben a történetiség jelen van a mindennapi politikában, s a történetiség sokkal mélyebb értelmü, semmint csak 1918-tól lehetne szemlélni (Rónai A. 1935, 1940, 1941, 1942).

$\mathrm{Az}$ 1938-as országgyarapodástól kezdve fokozatosan megjelenik és újrafogalmazódik az "új magyar birodalom” (Bulla B. 1939), de méginkább „Szent István birodalma” (Teleki P. 1941), valamint a Szent István-i állameszme foldrajzi tartalma (Kádár $L$. 1941, 1943, 1944). Ezek a megfogalmazások már egy korlátozott revízió igényét hordozták, csak a Szent István uralkodása időszakában magyar uralom alatt álló területekre jelentettek ,jogigényt".

Bulla Béla államföldrajzi és történeti földrajzi elemzéseiben arra a következtetésre 
jutott, hogy a magyar állam történetileg szervesen nött bele a Kárpát-medencébe, $s$ a táj és nép, a magyar állam és a Kárpát-tér elválaszthatatlan egymástól ( $B u l l a B$. 1939). Az országgyarapodások időszakában megjelent „új magyar birodalom” Bulla szerint csak gazdasági alapokon jöhet létre.

Prinz az 1940-es években világos különbséget tett az ország és az állam, az országhatár és az államhatár között: „Az ország természetes területegységet, az államterület ellenben adott idöpontban való uralmi terület egységet jelent...”; ,A magyar országhatár, a természetes magyarországi területegység határa...", az államhatár pedig az éppen aktuális 1942-es államterület határa (Prinz Gy. 1942, 15. o.).

Az Államtudományi Intézet Közép-Európa Atlasza a háború végén jelent meg, összegezve az intézet mintegy két évtizedes tudományos tevékenységét (Rónai $A$. 1945). Az atlasz szinte mindenre kiterjedően korrekt tudományos szintézist nyújtott az egész térségröl.

Az 1945 után új feltételek közé került magyar társadalomtudomány sok vonatkozásban megörizte a korábbi szemléletét, de kísérleteket tett az új helyzetben a reális folyamatelemzésekre, $\mathrm{s}$ a térségi kapcsolatok történeti elemeinek újrafogalmazására is (Radisics E. szerk. 1946, Elekes D. szerk. 1947, Anon. 1948).

A magyar földrajztudomány is szakitott korábbi stílusával, de az államterületre vonatkozó szemlélete csak mérsékelten változott meg. Bulla és Mendöl monográfiája (Bulla B.-Mendöl T. 1947) e tekintetben inkább a folyamatosságot tartotta fenn - természetesen a megváltozott helyzetnek megfelelő korrekciókkal - nevezetesen, hogy nem a magyar állam, hanem a Kárpát-medence fơldrajzát írták meg, s mintegy csak véletlenszerü, hogy a két térfogalom történetileg nagyjából egybeesett, de 1918 óta több állam osztozik e természetes nagytájon.

A II. világháború utáni területi folyamatokat politikai foldrajzi szempontból elemző Rónai-tanulmány 1947-ben még megjelenhetett, ekkor még elemezhette Közép-Európa területi problematikáját, de 1948/49 után a kérdések ilyetén való felvetése „elvesztette cél- és idöszerüségét”.

\section{Összegzés}

A magyar államterület történeti fejlödése rendkívül bonyolult, többszakaszos és többösszetevős folyamat volt. Ennek a folyamatnak mindenkori közjogi szabályozása és megjelenitése nagyrészt korszakhoz kötött módon jelent meg.

A területi átstrukturálódások a 18. századtól kezdve kiváltották a földrajztudomány érdeklödését is, $\mathrm{s}$ a magyar államtérszemlélet egyik fontos diszciplínájává vált a magyar földrajztudomány.

A dualizmus időszakának magyar geográfusai a történeti struktúraelemzéseket a nemzeti egyenrangúság bizonyításának céljára használták fel. Be kivánták mutatni, hogy Magyarország ugyanúgy „birodalom történetileg”, mint Ausztria, sőt Ausztria jelentős területeket csak az „ösi magyar jogon” szerezhetett meg.

A fôldrajztudomány meghatározó képviselöi és müvelöi személyes veszteségként is 
meg kellett, hogy éljék a trianoni traumát (Cholnoky kolozsvári, Prinz pozsonyi egyetemi tanszékét, Teleki szükebb értelemben vett történelmi hazáját és birtokait, Fodor karánsebesi középiskolai tanári állását veszítette el). A Kárpátok leszakítása a magyar államtérről nagyfokú szakmai veszteséget is jelentett számukra.

Ezzel magyarázható, hogy a magyar geográfusok szinte kivétel nélkül részt vettek az 1918-as békeelökészítésben, az ország integritásának megvédéséért folytatott küzdelemben, sőt azt mondhatjuk, hogy motorjai voltak ezeknek a munkálatoknak. Nem véletlen, hogy a magyar földrajztudomány a két világháború közötti időszakban mind a történeti, mind pedig a napi történések szintjén egybekapcsolódott az államtér és államhatárok történeti kutatásával, sőt Teleki Pál révén az 1938-as komáromi tárgyalásokon a részbeni formálásával is.

A magyar földrajztudomány 1945-1948 között direkt külső, politikai erőszak nélküil végrehajtott egyfajta önkorrekciót, hangsúly- és a szomszédos országokkal kapcsolatban egyfajta hangnemváltást, de ennek hosszú távú kifutására az 1949-es fordulat miatt már nem volt lehetóség.

\section{Irodalom}

Acsády I. (I 896) Magyarország népessége a pragmatica sanctio korában. Országos Magyar Kir. Statisztikai Hivatal, Budapest.

ANON. (I9I8) A Magyar Földrajzi Társaság Szózata a világ Földrajzi Társaságaihoz. Földrajzi Közleméyek, 7-9. 289-320. 0.

ANON. (1948) Magyarország. (Történeti, gazdasági és kulturális évkönyv). Hungária Lloyd, Budapest.

Bajza J. (1925) A magyar-horvát unió felbomlása. Franklin-Társulat, Budapest.

Baráth T. (1943) Az országépités filozófiája a Kárpát-medencében. Nagy Jenő és Fia, Kolozsvár.

Bél M. (1735) Notitia Hungariae novae historico geographica. Vienna.

Bél M. ( I792a) Compendium Hungariae Geographicum. 4 kiadás. Landerer, Pozsony, Pest.

Bél M. (1792b) Compendium regnorum Slavoniae, Croatiae, Dalmatiae, Galliciae, et Lodomeriae, nagnique principans Transilvaniae Geographicum. Linderer, Pozsony, Kassa.

Bulla B. ( I934) Einige Zuge zum geopolitischen Bild des ungarischen Beckens. Ungarische Jahrbücher, 3. 249-254. o

Bulla B. (1938) Az új határ. Magyar Szemle. 4. (136) 308-319. o.

Bulla B. (I939) Magyar fòld, magyar sors. In: Az ezeréves Magyarország. Pesti Hílap Rt., Budapest, I5-90. o.

Bulla B. (194I) A trianoni Délvidék. Magyar Szemle, 6. (166.) 346-354 o.

Bulla B.-Mendöl T. (1947) A Karpát-medence földrajza. Egyetemi Nyomda, Budapest.

Cholnoky J. (szerk.) (I920) A magyar béketárgyalások, I-Ill. kötet. M. Kir. Külügyminisztérium, Budapest.

Cholnoky J. (é n.) Hazánk és népünk egy ezredéven át. Il. kiadás. Somló Béla Könyvkiadó, Budapest.

Cholnoky J. (é. n.) A Kárpátoktól az Adriáig. (Nagy-Magyarország írásban és képben). II. kiadás. Somló Béla Könyvkiadó, Budapest.

Cholnoky J. é. I. ( 1937 ) Magyarorszäg földrajza. Franklin-Társulat, Budapest.

Czirbusz Gy. ( I902) Magyarország a XX. évszázad elején. Polatsek Kiadása. Temesvár.

Czirbusz G. (1919) Antropo-geográfia III. Geopolitika. Franklin-Társulat, Budapest.

Donáth Gy. (1938) Az ezeréves Magyarország területe. Magyar Stalisztikai Szemle, Szent István szám, 9-18. o.

Eckhart F. (1941) A szentkorona-eszme története. Magyar Tudományos Akadémia, Budapest.

Edelényi-Szabó D. (1928) Magyarország közjogi alkatrészeinek és törvényhatóságainak területváltozásai. Magyar Statisztikai Szemle, 6. 648-714. o.

Edvi-lllés A.-Halász A. (1921) Magyarország gazdasági térképekben. VI. kiadás. Pallasz Nyomda, Bp

Elekes D. szerk. (1947) A mai Magyarország. (A második világháború és a párizsi békeszerzódés köverkezményei). Hungária Lloyd, Budapest.

Fényes E. (1847) Magyarország leirása. Beimel, Pest.

Fodor F. (1920) Magyarország gazdaságfóldrajzi térképe. Magyar FöIdrajzi Intézet Rt., Budapest. 
Fodor F. (1924) Magyarország gazdasági földrajza. Franklin-Társulat. Budapest.

Fodor F. (1949/1951) A magyar földrajztudomány története. Gépelt kézirat. MTA Kơnyvtár Kézirattára, Budapest.

Galletti, J. G. A. (1844) Egyeremi világismeret. Hartleben Konrád Adolf, Pest.

Gál I. (szerk.) (1942) Magyarország és a Balkán. (A magyar tudomány feladatai Délkeleteurópában).

Balkán-Könyvtár I. Magyar Kolugyi Intézet Balkán-Bizottsága, Budapest.

Gál I. szerk. (1947) Magyarország és Keleteurópa. Officina, Budapest.

Geszti L. (1944) A magyar állam déli határváltozásairól. In: Földrajzi Zsebkömyv, 1944. Budapest, Magyar Földrajzi Társaság, 87-94. o.

Hajdú Z. (1995/a) Geopolitical restructuring of East-Central Europe: Hungary as an example. In: (Ed.: Markku Tykkylainen) Local and Regional Deelopment During the 1990s Transition in Eastern Europe. 5-18. 0

Hajdú Z. (1995/b) A Dél-Dunántúl politikai fơldrajzi helyzetének tơrténeti változásai. In: (szerk.: Horváth Gy.) A Dunántúl szolgálatában. MTA Regionális Kutatások Központja, Pécs, 113-133. o.

Halász A. (1928) New Central Europe in economic maps. Gergely Bookseller, Budapest.

Havass R. (1889) Dalmácia visszacsatolása a Magyar Birodalomhoz. Preszburg Nyomda, Budapest.

Havass R. (1902) Magyar impérializmus. Budapesti Hirlap, Budapest.

Havass R. (1906) A budapest-spalatói vasút. Földrajzi Közlemények. XXXIV. 35-40. o.

Havass R. (1907) Dalmácia visszacsatolása. Müszaki Nyomda, Budapest.

Havass R. (1909) A trializmus földrajzi szempontból. Földrajzi Közlemények, 9. 380-390. o.

Havass R. (1912) Magyar gazdasági és hatalmi törekvések a tengeren. Fritz Nyomda, Budapest.

Havass R. (1913) Magyarország és a Balkán. (Szerbia, Bulgária, Románia). Gazdaságpolitikai tanulmány Fritz Nyomda, Budapest.

Herczegh G. (1987) Magyarország külpolitikája (896-1919). Kossuth Konyvkiadó, Budapest.

Hunfalvy J. (186.3) A Magyar Birodalom természeti viszonyainak leirása. I. kót. MTA0 Pest.

Ivánfi E. (1869) A Magyar Birodalom vagy Magyarország és népeinek cimerei. Pest, Lauffen Vilmos

Kalmár G. (é. n.) Magyar geopolitika. Stádium, Budapest.

Kádár L. (1941) A magyar nép tájszemlélete és Magyarország tájnevei. Országos Táj- és Népkutató Intézet. Bp.

Kádár L. 1943) A Szent István-i eszme fóldrajzi alapjai. Délvidéki Szemle, 10. 467-475. o.

Kádár L. (1944) Térszemlélet és történelmi sors. In: A Magy. Kir. Keleti Kereskedelmi Föiskola Évkönye az 1934-1944. tanévrôl. Újvidék, 14-21. o.

Keleti K. (1871) Hazánk és népe a közgazdaság és társadalmi statistika szempontjából. Athenaeum, Pest.

Kogutowicz K.-Mákó J. (szerk.) (1920) Pesti Hirlap Térkẻp Albuma. Légrády Testvérek. Budapest.

Kollányi K. ( 1991) A Kárpát-medence Euröpában. HungAvia. Kráter. Budapest.

Kring M. (1934) A magyar államhatár kialakulásáról. In: A bécsi gróf Klebelsberg Kuno Magyar Történetkutató Intézet Évkönyve, IV. Budapest, 3-26. o.

Lóczi Lóczy L. (szerk.) (1918) A Magyar Szent Korona Országainak földrajzi, társadalommadományi, közmũvelódési és kỏzgazdasági leírása. Magyar Földrajzi Társaság kiadása. Kilián Frigyes utóda., Budapest.

Losontzi 1. (1795) Hármas Kis Tükör. Weinmüller Bálint, Komárom.

Magda P. (1819) Magyar Országnak és a határ örzö katonaság vidékinek legüjabb statistikai és geographiai leirása. Trattner János, Pest.

Marczali H. (1920) A béke könyve. Athenaeum, Budapest.

Mendol T. (1934) Az új szentistváni haza népei. In: Földrajzi Zsebkönyv, 1943. Magyar Foldrajzi Társaság, Budapest, 65-69. o.

Milleker R. (1917) A politikai földrajz alapvonalai. Csáthy Nyomda, Debrecen.

Molnár K (1929) Magyar közjog. Danubia, Pécs. (Harmadik kiadás)

Nagy L. (1993) Magyarország Európában. (A honfoglalástól a közelmúltig). Honffy Kiadó, Budapest.

Olay F. (1930) Csonka-Magyarország hatärairól. Franklin-Társulat, Budapest.

Palotás Z. (1990) A rrianoni határok. Interedition, Budapest.

Prinz Gy. (1914) Magyarország földrajza. A magyar föld és életjelenségeinek oknyomozó leirása. Magyar Földrajzi Társaság Rt., Budapest.

Prinz Gy. (1942) Magyarország földrajza. Renaissance Könyvkiadó, Budapest.

Prinz Gy. (1943) Hat világrész földrajza. Renaissance Konyvkiadó, Budapest.

Prinz Gy.-Teleki P.-Cholnoky J. (é. n.) Magyar Föld, Magyar Faj. Magyar Földrajz. I-III. köt. Királyi Magyar Egyetemi Nyomda. Budapest.

Ritter, G. A. (1909) Lander- und Völkerkunde. Berlin, 26. kiadás.

Rónai A. (1935) Keletkőzépeurópa államhatárainak életrajza. Gépelt kézirat. MTA FKI Könyvtára, Budapest. Rónai A. (1940) A magyar haza. Gépelt kézirat, MTA FKI Konyvtára, Budapest. 
Rónai A. (1941) Gondolatok a politikai földrajz témakorréböl. In: Az újságírójelölt kézikönyve 6. Stádium, Budapest, 77-125. o.

Rónai A. (1942) Hazánk. Országos Közoktatási Tanács, Budapest.

Rónai A. (1945) Közép-Európa atlasza. Államtudományi Intézet, Balatonfured-Budapest.

Rónai A. (1947) Területi problémák Közép-Európában. In: Magyar Földrajzi Társaság Zsebkönyve. Magyar Foldrajzi Intézet Rt., Budapest, 65-85. o.

Rónai A. (1989) Térképezett történelem. Magvetó Könyvkiadó, Budapest.

Sallai J. (1995) Magyarország történelmi határai a térképeken. Püski, Budapest.

Schwartner M. (1809) Statistik des Königreichs Ungern. Ofen.

Szabó Pál Z. (1945) Horvátország és mai részei a magyar tơrténelemben. In: Fóldrajzi Zsebkönyv, 1945. Magyar Foldrajzi Társaság, Budapest, 210-233. o.

Szaller Gy. (1796) Magyarország földleirásának rövid foglalattya egygy hozzá tartozandó ujonnan rajzoltt mappával egygyütt. Schauff János, Pozsony.

Szászky Tomka J. (1777) Introductio orbis antiqui et geographiam. Landerer, Pozsony, Kassa.

Teleki P. (1923) The evolution of Hungary and its place in European history. The McMillean Company, New York.

Teleki P. (é. n.) (1934) Európáról és Magyarországról. Athenaeum, Budapest.

Teleki P. (1941) Szent István birodalma 194l-ben. Budapest.

Tomcsányi M. (1942) Magyarország közjoga. Kir. Magyar Egyetemi Nyomda, Budapest (Negyedik kiadás)

Vályi A. (1796) Magyar Országnak leirása. Királyi Universitas. 1. kötet, Buda.

Werbỏczy I. ( I897) Hármaskönyv. Magyar Törvénytár, Franklin-Társulat, Budapest.

\title{
HISTORICAL AND POLITICAL GEOGRAPHICAL VIEWS OF THE TRANSITIONS OF THE TERRITORY OF THE HUNGARIAN STATE UNTIL 1948
}

\author{
ZOLTẢN HAJDÚ
}

The territory of the Hungarian state changed and rearranged very many times during history. Until 1526 the active (in some directions conquering) role of the Hungarian state was a dominant content of the changes, Hungary reached the status of a regional power in Central Europe. Following 1526 Hungary became a buffer region between the great powers, after 1710 it was part of the Habsburg Empire, with a relative independence. After 1867 the inner state structure of the Austro-Hungarian Monarchy was provided by the Constitution. The 20 th century brought frequent and radical transitions in the territory of the state.

Modern Hungarian geography, from its birth, paid great attention to the researches of the historical problems of the state territory. The notion of the historical "Hungarian Empire" and the imperial role had significant everyday political relevance. The awareness of the imperial past organically integrated into Hungarian geography, in broader sense into the Hungarian public thinking.

Following the fall in 1918 and the Trianon Treaty in 1920, the whole of Hungarian geography was claiming territorial revision. The historical territory of the Hungarian state and the historical Hungarian spirit were given everyday political content.

Between 1945-1948 a kind of self-correction occurred in the Hungarian geography, which could mainly be seen in the change of style. Historically, however, it could not fully develop, due to the political and systemic change of 1949. 